\title{
COMPARATIVE STUDY OF PULSED MICROWAVE AND HYDRODISTILLATION EXTRACTION OF PIPERINE OIL FROM BLACK PEPPER
}

\author{
Olusegun Abayomi Olalere* , Hamid Nour Abdurahman, Rosli MoHd \\ YunuS, OlUWASEUn RUTH AlaRA AND JAYSHREE THRAISINGAM \\ Faculty of Chemical Engineering \& Natural Resources, Universiti Malaysia Pahang, \\ Lebuhraya Tun Razak, 26300 Gambang, Pahang, Malaysia. \\ *Corresponding author: abrahman@ump.edu.my \\ (Received: 17 $7^{\text {th }}$ Feb. 2017; Accepted: $31^{\text {st }}$ Oct. 2017; Published on-line: $1^{\text {st }}$ Dec. 2017)
}

\begin{abstract}
Black pepper is a tropical crop with an extensive medicinal potential in ethnomedicine and nutraceutical applications. The pungent bioactive piperine is responsible for this functions which efficacy requires an efficient technologies for optimal extraction process. There is therefore a need to determine the best factor settings that optimize the relative efficiency of the system with minimal variability. In this study, the best factor settings was achieved using Taguchi parametric $\mathrm{L}_{9}$-orthogonal methodology. The extraction parameters considered under this study were extraction time, microwave power, particle size and molar ratio. An optimal extraction condition was achieved at $90 \mathrm{~min}$ extraction time, $350 \mathrm{~W}$ microwave power, $0.105 \mathrm{~mm}$ particle size and $10 \mathrm{ml} / \mathrm{g}$ molar ratio. The signal-to-noise ratio (SNR) otherwise known as response optimizer is an ideal metric in the determination of this optimum condition. The performance evaluation of reflux microwave extractor in relation to the hydrodistillation system placed the optimal efficiency and signal-to-noise ratio at $155.72 \%$ and 43.85 , respectively. The higher optimal efficiency obtained indicated that the microwave reflux extraction is better and more efficient than the conventional hydrodistillation techniques.
\end{abstract}

ABSTRAK: Lada hitam adalah tanaman tropika yang kaya dengan faedah perubatan terutamanya dalam perubatan alternatif dan bidang nutraseutikal. Kehadiran piperina iaitu unsur kimia yang tergolong dalam kumpulan alkaloid menjadi penyumbang utama bagi kepedasan yang dihasilkan oleh rempah ini sekaligus berperanan besar dalam menjadikannya satu bahan yang memiliki nilai perubatan yang tinggi. Keberkesanan fungsi lada hitam ini bergantung penuh pada teknologi pengekstrakan yang cekap bagi memastikan proses pengasingan yang optimal dapat dijana. Sehubungan itu, penentuan faktor terbaik yang dapat mengoptimumkan keberkesanan relatif sistem pengekstrakan dengan pemboleh ubah dan ralat yang minimal perlu dikenal pasti. Faktor terbaik didapati dengan menggunakan parameter $\mathrm{L}_{9}$ Taguchi dalam rekaan ortagonal. Dalam kajian ini, parameter pengekstrakan yang dikaji ialah masa pengekstrakan, kuasa radiasi, saiz zarah dan nisbah molar. Pengekstrakan yang optimum tercapai pada minit ke-90 pengekstrakan, $350 \mathrm{~W}$ kuasa gelombang mikro serta pada saiz zarah $0.105 \mathrm{~mm}$ dan nisbah molar $10 \mathrm{ml} / \mathrm{g}$. SNR (signal to noise ratio) adalah metrik ideal yang diguna pakai untuk mendapatkan keadaan optimum tersebut. Perbandingan dari segi keberkesanan kaedah pengekstrakan refluks menggunakan gelombang mikro dengan kaedah penyulingan hidro menunjukkan bahawa kaedah pengekstrakan refluks menggunakan gelombang mikro memiliki keberkesanan optimum pada $155.72 \%$ dan SNR sebanyak 43.85. Nilai keberkesanan optimal yang tinggi ini secara jelasnya membuktikan bahawa kaedah pengekstrakan refluks menggunakan gelombang mikro lebih efektif berbanding 
kaedah konvensional penyulingan hidro sekaligus menjadi indikator bagi pengekstrakan tanpa degradasi.

KEYWORDS: black pepper; extraction; piperine; hydrodistillation; microwave extraction; Taguchi optimization

\section{INTRODUCTION}

Piper nigrum otherwise called black pepper is an important agricultural crop with economical, nutritional and health benefits. It is used as spices in the food industry, in traditional medicine as anti-rheumatic, in pharmaceuticals as an analgesic, essential balm production as an adiabatic substance, and also as tear gas components in policing [1-3]. There are however more than a thousand known species characterized by distinguishing pungency and flavoring properties [4]. Black pepper is a climbing perennial plant, grown in many parts of India, Brazil, Indonesia, Sri Lanka, Vietnam, and Malaysia [5]. Their flavoring and pungency properties is due to the presence of volatile and non-volatile oil containing an active compound called piperine [6]. Other analogous active components in black pepper include piperettine, piperanine, piperyline-A, piperolein-B and pipericine. Piperine is thereafter the active alkaloid reponsible for the pungent characteristics of black pepper. It hydrolyzes in aqueous alkali to forms a slightly pungent photosensitive isomer called piperidine. Recent studies have shown the ability to boost the bioavailability of nutrients from other nutrients with an inhibitory capacity to cancer, inflammation, pain, and depression [8]. Many studies had been conducted on the improvement and implementation of distinctive operating conditions for the extraction of piperine oil using different methods [9][10]. Rafajlovska et al. [11] used solvent extraction method to extract piperine oil under distinctive conditions of extraction time, temperature and solvent type. Nahak and Sahu [12], isolated piperine from black pepper fruits with ethanol using the column chromatography method. The mass spectra obtained revealed the presence of a compound with a molecular weight $284.5 \mathrm{gmol}^{-1}$ which confirmed the presence of piperine. Raman and Gaikar [13] investigated the use of microwave assisted technique to extract piperine oil from granular black pepper seeds. The extraction factors considered were the microwave power level, solvent type and solid loading. The results revealed that the selective extraction resulted in the production of high-quality piperine with $85 \%$ purity.

In this study, the effects of microwave extraction parameters (irradiation time, microwave power level, feed particle size, and molar ratio) on the extraction yield and relative efficiency were investigated. The microwave reflux extraction works on the principle of ionic conduction and dipole rotation. Due to their electromagnetic nature, microwaves possess electric and magnetic fields which are at right. The electric field generated inside the microwave induces an ionic current in the solution which triggers off the extraction process [14]. The relative efficiency of the microwave extraction technique was estimated based on their extraction yield in relation to that of the conventional hydrodistillation extraction method.

\section{EXPERIMENTAL}

\subsection{Plant Materials Preparation}

The dried reticulated wrinkled brown surface black pepper was purchased from Sarawak, Malaysia. The seeds were then grinded and clarified into five different particle sizes $(0.105 \mathrm{~mm}, 0.154 \mathrm{~mm}, 0.30 \mathrm{~mm}, 0.450 \mathrm{~mm}$ and $0.90 \mathrm{~mm})$. 


\subsection{Extraction Process}

\subsubsection{Exhaustive Hydrodistillation Extraction}

An accurately weighed $5 \mathrm{~g}$ of the powdered black sample was loaded into round bottom reactor containing distilled water at 1:20 feed-to-water ratio [9]. The pepper feedstock was hydrodistilled step-wisely for $4 \mathrm{hr}$ with the first extraction step-wisely carried out using $75 \mathrm{ml}$ of distilled water for the first $2 \mathrm{hr}$ and the second extraction process for another $90 \mathrm{~min}$ using $30 \mathrm{ml}$ of water. With a $10 \mathrm{ml}$ of water for the last $30 \mathrm{ml}$ part of the extraction process in accordance with the method used by [15]

\subsubsection{Microwave Reflux Extraction}

An easy-controled automated microwave extraction system was employed for this study (Milestone Inc., North America). The auxiliary units attached to the system include magnetic stirrer, exhaust outlet, beam reflector, a reflux unit, and a magnetron of 2450 $\mathrm{MHz}$ with a nominal maximum power of $1000 \mathrm{~W}$. A $5 \mathrm{~g}$ of the powdered dried sample at different particles sizes were loaded into the reactor containing a measure distilled water. Three-level pulsed heating modes and this includwere used viz: $10 \mathrm{~min}$ of pre-heating mode $\left(100{ }^{\circ} \mathrm{C}\right)$, irradiation mode $\left(60^{\circ} \mathrm{C}\right)$ and cooling for $10 \mathrm{~min}\left(30^{\circ} \mathrm{C}\right)$. The application of pulsed heating reduces the variation imposed upon by noise factor (temperature) [16].

\subsection{Determination of Piperine Yield}

Moreover, an Agilent GC-MS (5973N Wilmington, DE, USA) equipped with a C-18 capillary column of length $30 \mathrm{~m}$, the internal diameter of $0.25 \mathrm{~mm}$ and film thickness 0.25 $\mu \mathrm{m}$. This was used to determine the composition of the piperine in the Piper nigrum sample at different parameter settings at an electron mode of $70 \mathrm{eV}$. The components of the spice oil extract were obtained using a computer controlled GC-MS system. The basis of their component identification was based on the retention indices and mass spectra matching in relation with the NIST spectral libraries [17]. This was carried out by diluting the extract with an analytical standard grade acetone at a ratio 1:10.1 $\mu$ l. This was then injected into the GC-MS for piperine detection and quantification. The actual percentage of piperine was calculated using the normalization techniques in relation to the quantity of the sample loading as shown in Eq. (1).

$$
P Y(\%)=\frac{\text { Amount of piperine content }}{\text { Sample mass }} X 100
$$

\subsection{Determination of Relative Efficiency}

The relative index is a performance evaluation tools used in determining the efficiency of one extraction technique over the other [14]. This is the ratio of yields from microwave reflux extraction (MRE) to conventional hydrodistillation (HD). The ratio of the piperine yield in MRE relative to HD was estimated for each experimental run in the design matrix. It is a dimensionless value which only reveals the proportion in which one extraction technique out-performed the other. The relative efficiency is therefore obtained by multiplying the relative index by 100 as shown in Eq. (2).

$$
R E E(\%)=\frac{\text { Yield from optimal condition of MRE technique }}{\text { Yield from HD technique }} * 100
$$




\subsection{Determination of Factor Operating Levels}

The extraction parameters under investigation were the irradiation time (A), microwave power level (B), feed particle size (C), and the molar ratio (D). Three levels were selected from parameters variation as presented in Table 1.

Table 1: Extraction factors and levels

\begin{tabular}{lllll}
\hline Extraction variables & Annotation/ Units & Level 1 & Level 2 & Level 3 \\
\hline Irradiation time & A (min) & 30 & 60 & 90 \\
Microwave power & B (W) & 300 & 350 & 400 \\
Feed particle size & C (mm) & 0.105 & 0.154 & 0.300 \\
Molar ratio & D (mL/g) & 6 & 8 & 10 \\
\hline
\end{tabular}

\subsection{Optimized Taguchi Experimental Design}

The Taguchi experimental design is an orthogonal optimization array which offers flexibility in the choice of optimal product or process conditions, with a high performance and consistency in operation. This design takes into consideration that not all process parameters can be controlled in practical reality and these process parameters are called noise or uncontrollable factors [18]. From the experimental design matrix in Table 2, the optimum extraction conditions for the black pepper relaxation were obtained at $90 \mathrm{~min}$ irradiation time (A), $350 \mathrm{~W}$ power level (B), $0.105 \mathrm{~mm}$ feed particle size (C) and $10 \mathrm{ml} / \mathrm{g}$ molar ratio (D). At the optimal level was attained at trial-8 with relative efficiency and signal-to-noise ratio of $155.72 \%$ and 43.8469 , respectively. According to Olalere et al. [20], the optimal condition is the point with the largest SNR (trial-8) as illustrated in Fig. 1.

Table 2: Design Matrix and Orthogonal Test Results for $\mathrm{L}_{9}\left(3^{\wedge} 4\right)$

\begin{tabular}{cccccccc}
\hline Run & A (min) & B (W) & C (mm) & D (ml/g) & \multicolumn{2}{c}{ Responses } & SNR \\
\cline { 6 - 7 } & & & & & PY(w/w) & REE $(\%)$ & \\
\hline 1 & 30 & 300 & 0.105 & 6 & 1.39 & 105.69 & 40.48 \\
2 & 30 & 350 & 0.154 & 8 & 0.70 & 52.83 & 34.46 \\
3 & 30 & 400 & 0.300 & 10 & 0.72 & 54.16 & 34.67 \\
4 & 60 & 300 & 0.154 & 10 & 1.19 & 90.35 & 39.12 \\
5 & 60 & 350 & 0.300 & 6 & 1.11 & 84.10 & 38.50 \\
6 & 60 & 400 & 0.105 & 8 & 0.87 & 65.64 & 36.34 \\
7 & 90 & 300 & 0.300 & 8 & 0.59 & 44.32 & 32.93 \\
8 & 90 & 350 & 0.105 & 10 & 2.056 & 155.72 & 43.85 \\
9 & 90 & 400 & 0.154 & 6 & 0.77 & 58.00 & 35.27 \\
\hline
\end{tabular}

A: Irradiation time, B: Microwave power, C: Feed particle size, D: Molar ratio, PY: Piperine yield, REE: Relative extraction efficiency, SNR: Signal-noise ratio 


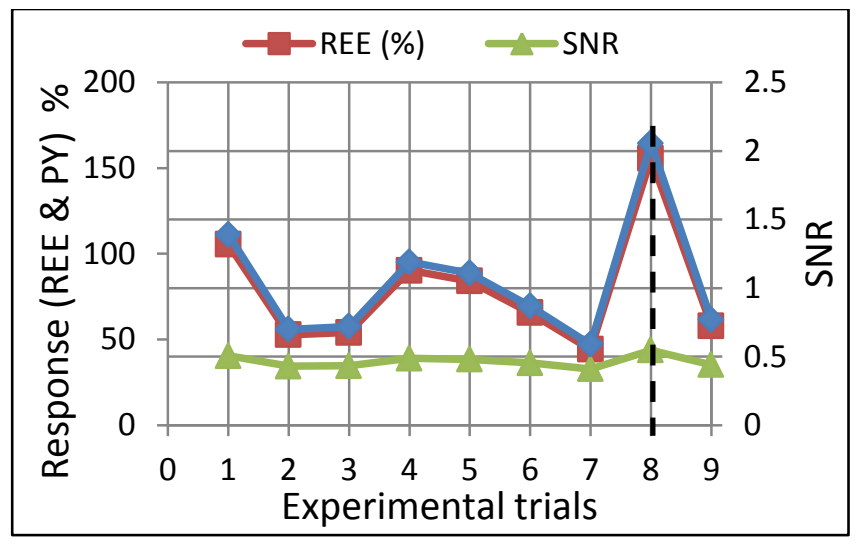

Fig. 1: The graphical illustration of SNR in relation to the REE.

\section{RESULTS AND DISCUSSION}

\subsection{Analysis of Response Means}

The sample was hydrodistilled and validated under the same operating conditions and results indicated that the average mean of the piperine yield was $1.322 \mathrm{w} / \mathrm{w}$, with relative standard deviation (RSD) of $0.92 \%$ using water as the extracting agent. However, the optimal response characteristics mean was computed for each of the microwave extraction parameters using the larger-the-better quality characteristics [19]. From the results obtained from the analysis of mean (ANOM); the sample particle size played the most significant contribution. Increasing the surface area of the pepper led to an improved efficiency (109.02\%) as presented in Table 3. However, irradiation time gave the least contribution to the piperine yield which suggested that the optimal efficiency can only be achieved at minimal microwave time [11].

Table 3: Average main effects

\begin{tabular}{ccccc}
\hline REE(\%) & A (min) & B (W) & C (mm) & $\begin{array}{c}\text { D } \\
(\mathbf{m l} / \mathbf{g})\end{array}$ \\
\hline Level 1 & 70.89 & 80.12 & 109.02 & 82.60 \\
Level 2 & 80.03 & 97.55 & 67.06 & 54.26 \\
Level 3 & 86.01 & 59.27 & 60.86 & 100.08 \\
\hline Delta Difference & 15.12 & 38.28 & 48.16 & 45.81 \\
\hline Optimal Ranking & 4th & 3rd & 1st & 2nd \\
\hline A:Irradiation time, B: Microwave power, C. Feed particle size, D: Molar ratio,
\end{tabular}

REE: Mean relative efficiency

From the characteristic means, the maximum efficiency was attained at the $3^{\text {rd }}$ level setting $(90 \mathrm{~min}$ ) with a relative extraction efficiency of $86.01 \%$ (Fig. 2). This suggested that, as the irradiation time increased, the piperine yield increased. The higher optimal irradiation time could, therefore, be attributed to the higher molecular weight (285.34 $\mathrm{g} / \mathrm{mol}$ ) of piperine which involves longer time in breaking the forces of attraction holding their molecules together [21]. Furthermore, the slope from main effect plots (Fig. 2) gave a maximum response mean at power level-2 $(350 \mathrm{~W})$ indicating an improved yield with a mean response value $97.55 \%$. Also, the optimal response means for the feed particle size was estimated to be $109.2 \%$ at level-1 with a mesh size-140 (0.105 mm). Optimum 
piperine yield was therefore obtained with a finely divided powdered pepper as compared with a more coarse size. This suggests that smaller particle size provides the good surface area with increase efficiency [22]. Furthermore, the mean response efficiency of $82.60 \%$ was obtained at level-3, confirming that a higher molar ratio of $10 \mathrm{ml} / \mathrm{g}$ is required at optimum condition [23].

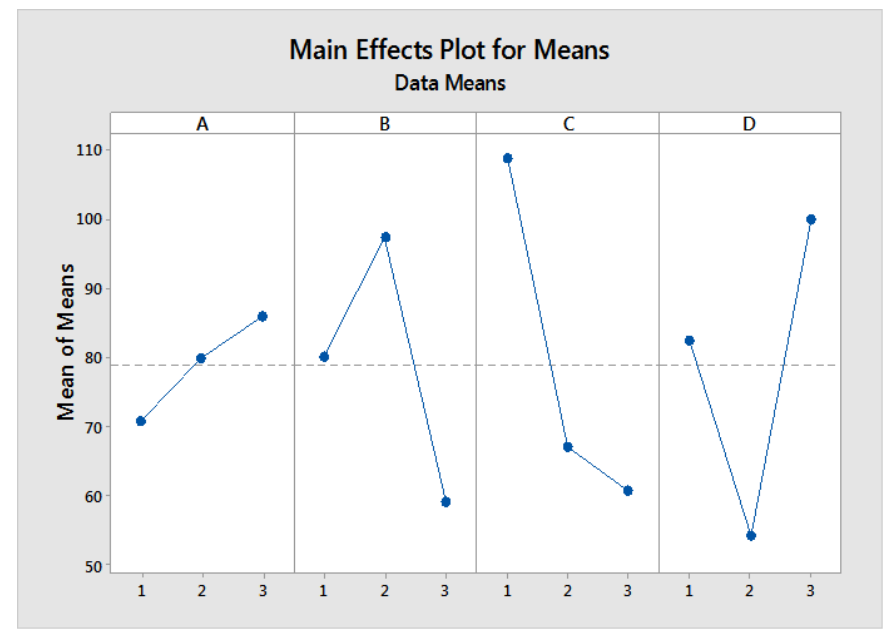

Fig. 2: Response Graph Illustrating variations of REE mean.

\section{CONCLUSION}

In the extraction of bioactive compounds from plant origin, the efficiency of the extraction procedure is often neglected. The relative efficiency is therefore the basis for measuring the productivity of an extraction method on an industrial scale. The determination of an optimal efficiency of microwave extractors could therefore be employed as performance index in the future scale up. This could be applied in the quantitative comparison between two or more extraction methods. This study compared the relative efficiency of microwave reflux with respect to the exhaustive hydrodistillation techniques. The effect of process parameters such as microwave power, irradiation time, feed particle size, molar ratio and signal-to-noise ratio characteristics were succinctly investigated. The performance evaluation of reflux microwave extractor in relation to the exhaustive hydrodistillation system gave an optimum efficiency of $155.72 \%$. This indicated that the extract prepared using the microwave extractor presented a better extraction efficiency than the exhaustive hydrodistillation system.

\section{ACKNOWLEDGEMENTS}

We acknowledge the financial contribution of Research and Innovation Department Universiti Malaysia Pahang (UMP), Malaysia through the grant PGRS-160320.

\section{REFERENCES}

[1] Viktorija M, Liljana KG, Tatjana R, Rubin G. (2014) Antioxidative effect of Capsicum oleoresins compared with pure capsaicin. IOSR J. Pharm. 4:44-48.

[2] Nwokem C, Agbaji E, Kagbu J, Ekanem E. (2010) Determination of capsaicin content and pungency level of five different peppers grown in Nigeria. NY Sci J. 3:17-21.

[3] Adkins LD (2003) Oleoresin capsicum: an analysis of the implementation of pepper spray into the law enforcement use of force continuum in a selected police department. Electron. 
Theses Diss.86. http://dc.etsu.edu/etd/779.

[4] Vasavirama K, Upender M. (2014) Piperine: A valuable alkaloid from piper species. Int. J. Pharm. Pharm. Sci. 6:34-38.

[5] Ha YM, Li WM, Wang F. (2011) Application of ESR spectroscopy to identify and estimate original dose in irradiated cumin and white pepper, Eur. Food Res. Technol. 233:625-630.

[6] Meghwal M, Tk G. (2012) Nutritional constituent of black pepper as medicinal molecules: Open Access Scienctific Reports 1:129.

[7] Majeed, Prakash L. (2000) The medicinal uses of pepper. International Pepper News, 25:2331.

[8] Janakiraman K, Manavalan R. (2008) Studies on effect of piperine on oral bioavailability of ampicillin and norfloxacin. Afr. J. Tradit. Complement. Altern. Med. 5:257-262.

[9] Olalere OA, Abdurahman HN, Yunus RM, Alara OR. (2017) Multi-response optimization and neural network modeling for parameter precision in heat reflux extraction of spice oleoresins from two pepper cultivars (Piper nigrum). J. King Saud Univ. - Sci. doi:10.1016/j.jksus.2017.09.010.

[10] Olalere OA, Abdurahman HN, Alara OR, Habeeb OA. (2017) Parametric optimization of microwave reflux extraction of spice oleoresin from white pepper (Piper nigrum). J. Anal. Sci. Technol. 8:1-8.

[11] Rafajlovska V, Slaveska-Raicki R, Klopcevska J, Srbinoska M. (2011) Extraction of oleoresin from pungent red paprika under different conditions, Mass Transf. Chem. Eng. Process. 5:111-132.

[12] Nahak G, Sahu RK. (2011) Phytochemical evaluation and antioxidant activity of piper cubeba and Piper nigrum, J. Appl. Pharm. Sci. 1:153-157.

[13] Raman G, Gaikar V. (2002) Microwave-assisted extraction of piperine from Piper nigrum, Ind. Eng. Chem. Res. 41:2521-2528.

[14] Mandal V, Mohan Y, Hemalatha S (2008) Microwave assisted extraction of curcumin by sample-solvent dual heating mechanism using Taguchi $\mathrm{L}_{9}$ orthogonal design, J. Pharm. Biomed. Anal. 46:322-327.

[15] Özek G, Demirci F, Özek T, Tabanca N, Wedge DE, Khan SI, Hüsnü K, Bas C, Duran A, Hamzaoglu E. (2010) Gas chromatographic - mass spectrometric analysis of volatiles obtained by four different techniques from Salvia rosifolia $\mathrm{Sm}$ and evaluation for biological activity, 1217:741-748.

[16] Chan CH, Lim JJ, Yusoff R, Ngoh GC. (2015) A generalized energy-based kinetic model for microwave-assisted extraction of bioactive compounds from plants. Sep. Purif. Technol. 143:152-160.

[17] Singh S, Kapoor IPS, Singh G, Schuff C, De Lampasona MP, Catalan CAN. (2013) Chemistry, antioxidant and antimicrobial potentials of white pepper (Piper nigrum L.) essential oil and oleoresins, Proc. Natl. Acad. Sci. India Sect. B - Biol. Sci. 83:357-366,

[18] Maghsoodloo S, Ozdemir G, Jordan V, Huang CH. (2004) Strengths and limitations of Taguchi's contributions to quality, manufacturing, and process engineering, J. Manuf. Syst.23: 73-126.

[19] Olalere OA, Abdurahman NH, Alara OR. (2017) Extraction, radical scavenging activities and physicochemical fingerprints of black pepper (Piper nigrum) extract, J. Food Meas. Charact.http://10.1007/s11694-017-9604-4.

[20] Olalere OA, Abdurahman NH, Alara OR, Habeeb OA. (2017) Optimized microwave reflux extraction and antioxidant activities of piperine from black and white Piper nigrum. Chem. Eng. Res. Bull.19:139-144.

[21] Zaveri M, Khandhar A, Patel S, Patel A. (2010) Chemistry and pharmacology of piper longum, Int. J. Pharm. Sci. Rev. Res. 5:67-76.

[22] Kormin F, Ahmed I, Yunus RM, Yusof ZA. (2010) The potential of modified microwave extraction system (mmes) to extract bioactive components from ferns. Int. J. Eng. Technol. 10:7-21.

[23] Jokic S, Velic D, Bilic M, Bucic-Kojic A, Planinic M, Tomasa S. (2010) Modelling of the process of solid-liquid extraction of total polyphenols from soybeans, Czech J. Food Sci. 28:206-212. 